\title{
Quality Characteristics of Biscuits Prepared from Wheat Flour and Biscuit Scrap Powder
}

\author{
Mohamed A. Elbasyouny ${ }^{1}$, Mohamed S. Kamar ${ }^{1}$, Ahmed E. Abdalla ${ }^{2}$ \\ ${ }^{1}$ Bisco Misr (The Egyptian Company for Foods) ${ }^{2}$ Faculty of Agri., Saba Basha, Alex. \\ Univ.
}

\begin{abstract}
This study was carried out to investigate the effect of adding different levels of biscuit scrap to wheat flour on chemical, physical and rheological properties of biscuit. The proximate chemical composition of biscuit samples was not significantly $(p \leq 0.05)$ affected by adding biscuit scrap. There was a significant increase in fat and calories of produced biscuit compared with control. The acrylamide levels in produced biscuits decreased by increasing biscuit scraps. The highest level of acrylamide was measured in control samples (294 $\mu \mathrm{g} / \mathrm{kg}$ dry weight), while the lowest level of acrylamide was measured in biscuit prepared with adding $50 \mathrm{~kg}$ biscuit scrap (197 $\mu \mathrm{g} / \mathrm{kg}$ dry weight). Physical and rheological properties were slightly affected by adding biscuit scrap. Thickness was increased from $0.4 \mathrm{~cm}$ in control to $0.48 \mathrm{~cm}$ in biscuits prepared with adding $50 \mathrm{~kg}$ scrap, meaning that prepared biscuits with more scrap was crispier than control biscuits. Data showed that the water absorption significantly increased with the increase of biscuit scrap powder. Biscuit scrap powder flour had slight effect on dough properties such as elasticity and extensibility. This work paves the way for manufacturers to use biscuit scrap safely in producing biscuits.
\end{abstract}

Key words: Characteristics, Quality, Biscuit, Biscuit Scrap.

\section{INTRODUCTION}

Bakery products are the most popular processed food items around the world (Caleja et al., 2017). Of these, biscuits represent the largest category of snack foods among bakery products because they are made from simple, cheap and easily available raw materials. They are widely consumed because they have a very acceptable taste with high nutritive value (Chauhan et al., 2015).Although biscuits vary in their shapes, sizes and composition, the three main ingredients are always flour, sugar and fat as butter or vegetable shortenings (Caponio et al., 2006). The four main processes to make biscuits are mixing, cutting, baking and packing (Okpalan and Egwu, 2015). Baking is a very important process to achieve good quality biscuits. This process transforms the physical and chemical characteristics of the dough when baked in an oven (Khater and Bahnasawy, 2014), where the temperature and time will be accurately controlled. The oven temperature affects the moisture loss during baking, which plays an important role in achieving a good texture and the structure of the biscuits (Sudha et al., 2007 and Mamat and Hill, 2014). The structure of the biscuits is formed, and free water evaporated when gluten and starch have been sufficiently hydrated. The evaporation starts from the dough surface, achieving about $2-5 \%$ moisture content in the final products (Khater and Bahnasawy, 2014). Baking also alters the colour of the biscuit surface; namely, the browning process. It is not possible to manufacture biscuits without producing some scrap, or biscuits which do not measure up to the standard demanded. The quantity will largely depend upon the skill and ability of the operative to correctly reset the equipment involved. Biscuits unsuitable for sale should be returned for incorporation in similar mixings. Burned or soiled biscuits should not be used again, but should be disposed of as animal food. There is a lack of information about the reuse of biscuits scrap 
in biscuits companies all over the world (Whitely, 1971 and Davidson, 2018). The most important characteristics of the quality of biscuits produced from any ingredients are its appearance, including shape, size and colour, as consumers can easily be influenced by the appearance of food products (Sudha et al., 2007). Although, biscuit product has an acceptable flavour and colour, an undesirable texture in a food product can easily be a factor that influences whether a customer will continue to purchase the product or not. Therefore, the development of biscuits must be carefully designed in order to meet the required physicochemical properties among various environmental conditions, such as processing and storage.

An understanding of the combination of the ingredients, together with baking process, has an important effect on the quality and colour of the final product (Andresen et al., 2013). Biscuit deterioration is usually associated with different phenomena, where three incidents are predominant; loss of crispiness, fat bloom, and rancidity. The latter is the most effective in generating off-flavors that would thereby most adversely contribute to the organoleptic quality of the hard dough biscuits leading to consumers' rejection (Robertson, 2010). Biscuit is a hygroscopic food product, that generally tends to absorb water vapor from surrounding environment and susceptible for fat degradation process by hydrolytic rancidity (Duncan, 2009). In dry bakery products like biscuits, the deterioration during storage is mainly caused by lipid oxidation and resultant oxidative rancidity (Calligaris et al., 2008). Acrylamide has been found in an extensive variety of bakery products which can cause severe health problems (Liu et al. 2008, Ye et al. 2011 and Yuan et al. 2011). Composition and processing conditions play an important role in acrylamide formation, as different ingredients have various amounts of free asparagine and reducing sugars available for the reaction for the formation of acrylamide in biscuits (Razia et al., 2016 and Gündüz et al., 2017).

After the manufacture of biscuits directly and during storage, physical properties and rheological characteristics as well as chemical composition and sensory evaluation must be measured. Therefore, the objective of this work was to produce sweet biscuits from wheat flour blended with various levels of biscuit scrap and determine the proximate chemical composition, physical and rheological properties of produced biscuits.

\section{MATERIALS AND METHODS \\ Materials and Chemicals}

\section{Sample collection and Preparation}

Wheat flour (72 \% extraction), sugar, shortening, vanillin, citric acid, table salt, orange flavor and bicarbonate were purchased from the supplier of the Egyptian company for foods, BiscoMisr, El-seyouf plant, Alexandria, Egypt.

\section{Chemicals:}

All chemicals and reagents used in this study were purchased from Sigma Aldrich, Fisher, Fluka, and from local scientific companies and they are all of analytical grade with highest purity.

\section{Methods}




\section{Production of Biscuits}

The sweet biscuit production was carried out as described by the confidential method of BiscoMisr, El-Seyouf plant, Alexandria. Different batches of biscuits were prepared with adding various levels of scarp as described in Table (1) and Figures (1 \& 2).

Table (1). preparation of biscuits added with biscuit scrap

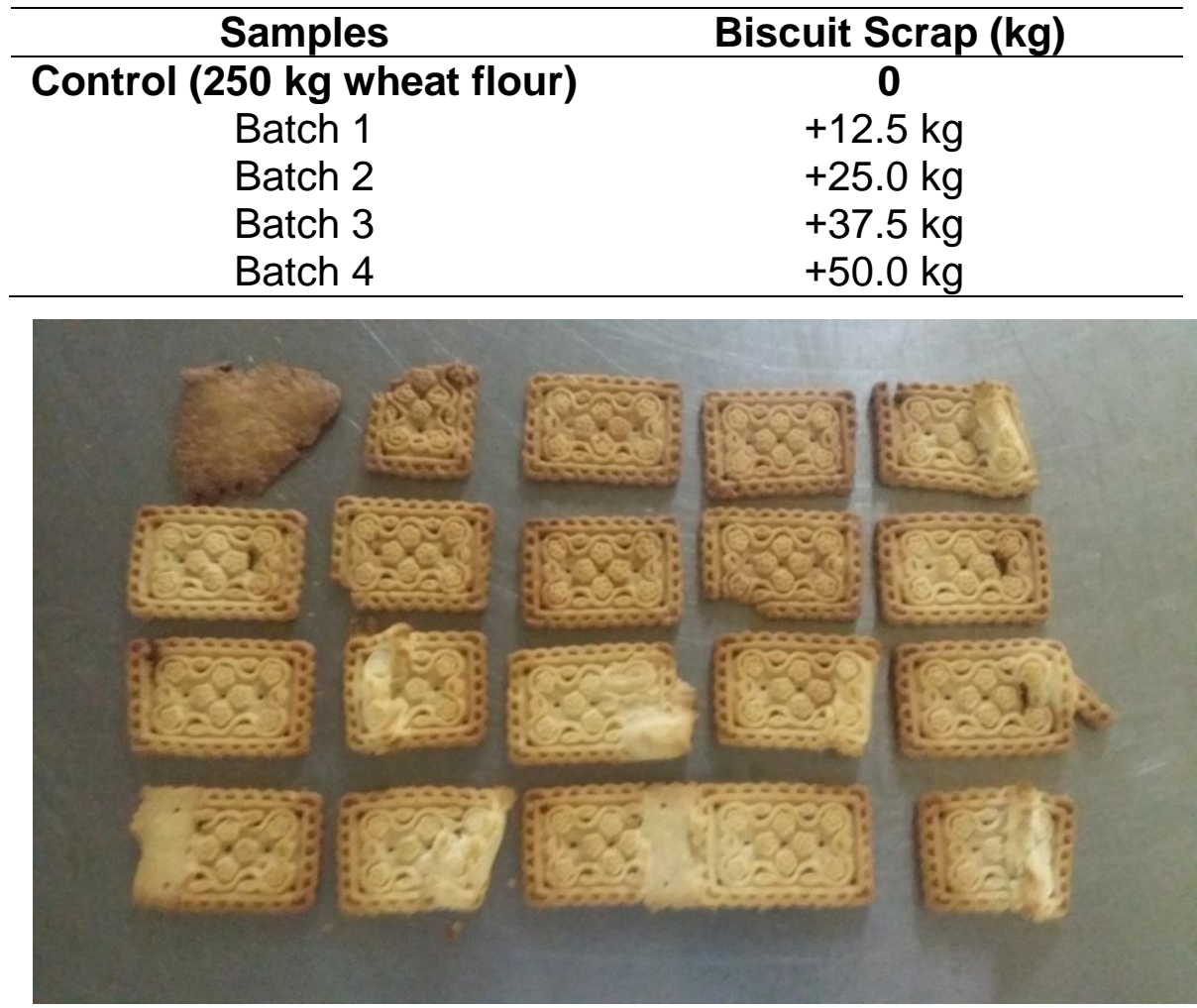

Figure (1). Types of biscuit scrap

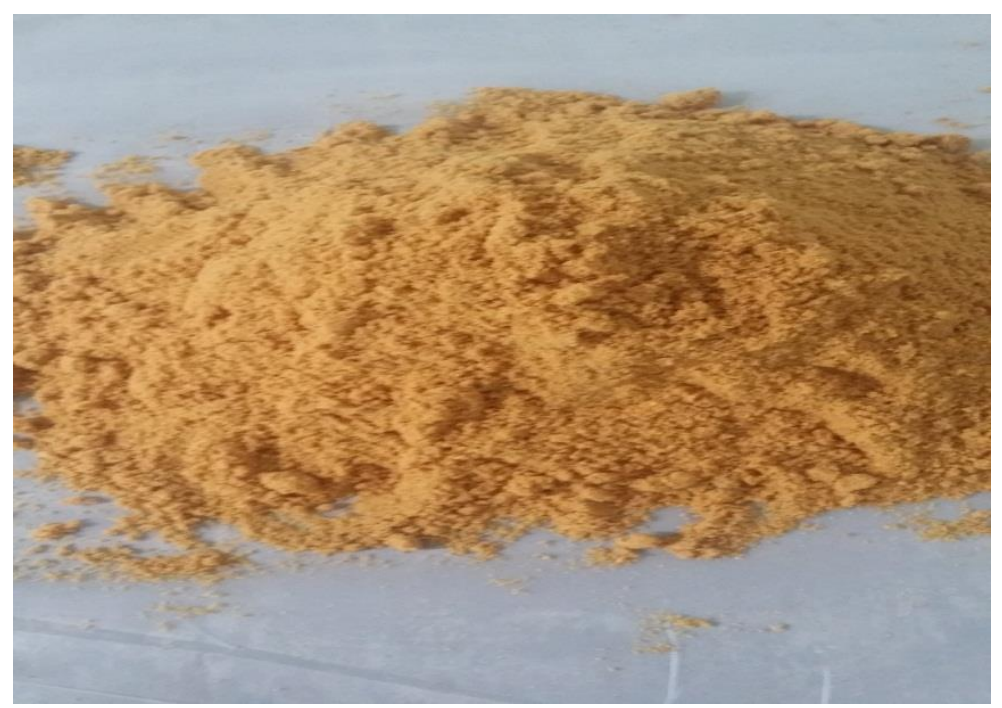

Figure (2). Biscuit scrap powder

\section{Analytical methods:}




\section{Proximate chemical composition:}

Moisture, crude protein, crude fat, ash, total dietary fiber and Nitrogen Free Extract (NFE) were evaluated in the different samples of biscuits as described by AOAC (2006). Nitrogen Free Extract (NFE) was calculated by difference. Energy values (Kcal/100g) were calculated as reported by Greenfield and Southgate (1992) applying the factors, 4, 9 and 4 for each $g$ of protein,lipids and carbohydrate, respectively, according to the following equation:

$$
\text { Energy }=4 \times(\text { protein }+g \text { carbohydrate })+9 \times(g \text { fat }) \text {. }
$$

\section{Acrylamide extraction and quantification}

All chemicals used were of high-performance liquid chromatography (HPLC) grade. All values of acrylamide content are expressed as micrograms per gram of fresh weight. The extraction of acrylamide was performed using milled biscuits $(2 \mathrm{~g})$ according to Gokmen et al. (2006).The LC/ESI-MS/MS analysis was performed with an HPLC system 1200 series (Shimadzu, Kyoto, Japan) coupled to an Agilent 6410 Triple Quad detector equipped with ESI interface. A Purospher STAR RP-8ec column $(150 \mathrm{~mm} 4.6 \mathrm{~mm}$, 3mm particle size, from Merck, Darmstadt, Germany, and an isocratic mixture of $100 \mathrm{~mL}$ of acetonitrile and $900 \mathrm{~mL}$ of aqueous solution of perfluorooctanoic acid $(0.05$ $\mathrm{mM})$ at a flow rate of $0.5 \mathrm{~mL} / \mathrm{min}$ were used. Deuterated acrylamide $(0.2 \mathrm{~g} / \mathrm{L})$ was used as internal standard. Three replicates were performed for each sample. flow rate $1 \mathrm{ml} / \mathrm{min}$ and temperature $250{ }^{\circ} \mathrm{C}$,column CLC-ODS reversed (phase) , wave length 25 um.

\section{Physical measurements of biscuits}

The weight $(\mathrm{g})$ for biscuit was determined individually within one hour after baking with an electronic balance Model SC6010 (Scout-Ohaus, U.S.A.). A desirable quality biscuit is expected to have great specific volume, which is the ratio of biscuit volume to biscuit weight. Protein content of grain was positively correlated with specific volume of biscuit. The average was recorded. The volume (cm3) of different types of produced biscuits was determined by rape seeds displacement method according to (Saadoudi et al., 2017). Specific volume was calculated using the following equation:

Specific volume $=$ Volume $\left(\mathrm{cm}^{3}\right) \div$ Weight $(\mathrm{g})$

\section{Color analysis of biscuits}

Each biscuit blend (0, 5, 10, 15 and $20 \mathrm{~kg}$ biscuit scrap with $250 \mathrm{~kg}$ wheat flour) was analyzed for crust color using the Hunter machine (Ultra Scan vis s/n: usvis 1310, Hunter Laboratory, USA) as described by Srivastava et al., (2010). The Ultra Scan Vis Color (illuminant /observers D65/10) was standardized before reading the samples and the readings were recorded with inbuilt software. The $\left(L^{*}, a^{*}\right.$ and $\left.b^{*}\right)$ values were recorded where $L^{*}=$ lightness, $a^{*}=\mathrm{red} / \mathrm{green}$, and $\mathrm{b}^{*}=$ yellow/blue. 


\section{Analyses of rheological properties of wheat / biscuit scrap powder blends dough}

\section{Determination of farinograph characteristics of blended dough}

Farinograph is frequently used to evaluate the rheological properties of dough such as water absorption of flour and to determine other characteristics of dough during mixing and establishes the flour behavior during the biscuit making process. Table (6) showed that rheological properties of wheat dough with different blends of biscuit scrap (12.5-50 kg BS). Dough development time, the time required for the dough development or time necessary to reach 500 Brabender unit (BU) of dough consistency. Stability value is an index of the dough strength.

Mixing properties of dough were evaluated using farinograph (Brabender OHG, Duisburg, Germany) according to AACC (2000) methods No. 54-10. In the farinograph, a dough was prepared under standardized conditions from $50 \mathrm{~g}$ of wheat flour. Farinograph data including water absorption: percentage of water required to yield dough consistency of 500 BU (Brabender Units), arrival time, dough development time: time to reach maximum consistency, stability time: time during dough consistency at 500 $\mathrm{BU}$ and degree of softening, centered on a 500-BU line. Dough types from wheat flour with the addition of variable quantities of biscuit scrap powder $(12.5,25.0,37.5$ and $50 \mathrm{~kg})$ were prepared from $300 \mathrm{~g}$ of these mixtures.

\section{Determination of extensograph characteristics}

The extensograph (Brabender OHG, Duisburg, Germany) measures elasticity (band width of the curve at the maximum consistency). The resistance to constant deformation after $50 \mathrm{~mm}$ stretching (R50), extensibility (E), ratio number: R50/E and area under beak for each blend were determined according to AACC (2000) methods No.54-21.

\section{Statistical analysis}

The results were reported as mean \pm standard deviation (SD) $(n=3)$. The average of obtained data was statistically investigated using one-way analysis of variance (ANOVA). To identify significant differences among means all studied parameters, Duncan test was performed (SPSS for Windows 16.0, USA). A statistical probability ( $p$ value) less than 0.05 indicated a statistically significant difference between samples (Steel and Torrie, 1980).

\section{RESULTS AND DISCUSSION}

\section{Chemical composition}

\section{Proximate chemical composition of prepared biscuits}

The proximate chemical composition of biscuits prepared from $250 \mathrm{~kg}$ wheat flour, biscuit scrap and prepared biscuits blended with biscuit scrape $(12.5,25.0,37.5$ and $50 \mathrm{~kg})$ are shown in Table (2). Wade and Stafford (1968) reported that the moisture content of different biscuits vary according to the 
type of biscuit produced, for example cream crackers has about $4.3 \%$ moisture content, digestive has about $4.5 \%$ and hard biscuits has about $2 \%$.

In this study, moisture content in prepared biscuits (1.97 to $2.10 \%$ ) was coinciding with Gupta (2001) and Sharma et al. (2016) who reported that moisture contents varied from 2.02 to $2.82 \%$ in biscuits prepared from wheat flour $72 \%$ extraction. The contents of moisture, protein, fiber and ash in prepared biscuits, biscuit scrap and biscuits blended with scrap were not significantly different. The values of protein content obtained in control biscuits $(11.30-11.50 \%)$ were in close agreement to the values reported by Sudha et al. (2007) and Sharma et al. (2016) for the biscuits prepared from wheat flour.

Fat content significantly ( $p \leq 0.05)$ increased with increasing the level of biscuit scrap, it increased from 14.30 in control biscuit to $15.55 \%$ on dry weight basis in biscuit blended with $50.0 \mathrm{~kg}$ scrap. Nitrogen free extract for control biscuit made of wheat flour $72 \%$ extraction $(72.30 \%$ of total dry weight) was in agreement with the result of Omran et al. (2016) and Rizk et al. (2016). Biscuit is an energy food which is taken mostly in food by both young and old person. The protein, fat and carbohydrate constituents of the flours contributed to know the calorie content of the biscuit samples. Energy values were calculated to be $463.9 \mathrm{Kcal}$ for prepared biscuits and $465 \mathrm{Kcal}$ for biscuit scrap and increased up to 469.03 for biscuit blended with $50 \mathrm{~kg}$ scrap due to high levels of fat in this sample. The results of energy in control biscuits (463.90) are in agreement with Youssef et al. (2016) who calculated that caloric value for prepared biscuits from wheat flour (72\% extraction) was 462.92. No published data was found on the chemical composition of biscuits blended with biscuit scrap.

\section{Acrylamide content in prepared biscuits}

The harmful effects of toxic chemical contaminants such as acrylamide in food pose a major health problem in the human being (Razia et al., 2016). Cereal products including biscuits, breads, crackers and breakfast cereals contain acrylamide at various levels. In 1994, the International Agency for Research on Cancer (IARC) classified acrylamide as potentially carcinogenic to human (Semla et al., 2017). In this study, the acrylamide contents in prepared biscuits are shown in Table (3). The data showed that the acrylamide levels significantly $(p \leq 0.05)$ decreased by increasing biscuit scraps. The highest level of acrylamide was measured in control samples $(294 \mu \mathrm{g} / \mathrm{kg})$, while the lowest level of acrylamide was measured in biscuit prepared from $250 \mathrm{~kg}$ wheat flour added with $50 \mathrm{~kg}$ biscuit scrap $(197 \mu \mathrm{g} / \mathrm{kg})$. It is well known that there is a strong correlation between acrylamide formation and baking temperature and time (Ahrné et al. 2007 and Keramate et al., 2011).

However, Ahrné et al. (2007) and Krishnakumar and Visvanathan (2014) found that increasing baking time up to $20 \mathrm{~min}$ at $260{ }^{\circ} \mathrm{C}$ decreased acrylamide concentration particularly in the outer crust, whilst its concentration in the inner crust was $25-75 \%$ that of the outer crust for baking at 200-230 ${ }^{\circ} \mathrm{C}$. So that the increasing biscuit scrap powder and repeated thermal 
treatment could reduce the amount of acrylamide in the biscuit products. It was published that the addition of consumable acids is a very simple but efficient method to reduce acrylamide in bakery products. When increasing amounts of citric acid $(0.1 \%$ or $0.2 \%)$ were added during manufacturing of biscuits, acrylamide deceased almost linearly without any impairment on taste of flavour (Jung et al., 2003, Graf et al., 2006 and Borda and Alexe, 2011). Moreover, it is referred that sodium bicarbonate has a role in changing $\mathrm{pH}$ that affects the acrylamide level (Eriksson, 2005 and Razia et al., 2016). Studies on the effect of $\mathrm{NaCl}$ in biscuits and wheat bread have shown that relatively low concentrations of $\mathrm{Na}+(1-2 \% \mathrm{w} / \mathrm{w})$ decreased acrylamide formation, whereas at higher level of salt the concentration was increased (Levine and Smith, 2005). The formula of sweet biscuit manufactured at BiscoMisr, Egypt contained sodium bicarbonate, ammonium bicarbonate and citric acid as well as table salt. So that low levels of acylamides in prepared biscuits added with biscuit scrap might be due to sodium bicarbonate and citric acid.

The Swedish National Food Administration in 2005 announced that foods processed and cooked at elevated temperatures have relatively high content of acrylamide (Zhang et al., 2005). It is reported that human are exposed by acrylamide from $20 \%$ bakery and $50 \%$ potato products (Eriksson, 2005). The toxic effects produced by oral doses of $>100 \mathrm{mg} / \mathrm{kg}$ of body weight and medium lethal doses (LD50) are $>150 \mathrm{mg} / \mathrm{kg}$ of body weight (JECFA, 2006). The following factors are affected in the formation of acrylamide in foods; such as processing conditions (i.e. temperature, moisture content, baking time and matrix of products).

Table (2). Proximate chemical composition of biscuits blended with different levels of biscuit scrap.

\begin{tabular}{|c|c|c|c|c|c|c|}
\hline $\begin{array}{c}\text { Constituents } \\
\%\end{array}$ & $\begin{array}{c}\text { Biscuit } \\
\text { (control) } \\
(250 \mathrm{~kg} \\
\text { wheat } \\
\text { flour) }\end{array}$ & $\begin{array}{l}\text { Biscuit } \\
\text { Scrap }\end{array}$ & $\begin{array}{c}+12.5 \mathrm{~kg} \\
\text { Scrap }\end{array}$ & $\begin{array}{c}+25 \mathrm{~kg} \\
\text { Scrap }\end{array}$ & $\begin{array}{c}+37.5 \mathrm{~kg} \\
\text { Scrap }\end{array}$ & $\begin{array}{c}+50 \mathrm{~kg} \\
\text { Scrap }\end{array}$ \\
\hline Moisture & $2.10 \pm 0.18^{a}$ & $2.00 \pm 0.20^{\mathrm{a}}$ & $2.18 \pm 0.22^{\mathrm{a}}$ & $2.13 \pm 0.21^{a}$ & $2.03 \pm 0.17^{\mathrm{a}}$ & $1.97 \pm 0.21^{\mathrm{a}}$ \\
\hline Crude protein* & $11.50 \pm 0.80^{b}$ & $11.30 \pm 0.88^{b}$ & $11.41 \pm 0.68^{b}$ & $11.34 \pm 0.81^{b}$ & $11.36 \pm 0.78^{b}$ & $11.32 \pm 0.86^{b}$ \\
\hline Crude fat ${ }^{*}$ & $14.30 \pm 0.90^{c}$ & $14.60 \pm 0.95^{\mathrm{cd}}$ & $14.68 \pm 0.65^{c d}$ & $15.24 \pm 0.75^{\mathrm{cd}}$ & $15.33 \pm 0.70^{\mathrm{cd}}$ & $15.55 \pm 0.95^{c d}$ \\
\hline Crude fiber* & $1.20 \pm 0.20^{\mathrm{e}}$ & $1.24 \pm 0.22^{\mathrm{e}}$ & $1.22 \pm 0.18^{\mathrm{e}}$ & $1.24 \pm 0.20^{\mathrm{e}}$ & $1.25 \pm 0.20^{\mathrm{e}}$ & $1.28 \pm 0.24^{\mathrm{e}}$ \\
\hline Total ash* & $0.70 \pm 0.10^{f}$ & $0.76 \pm 0.13^{f}$ & $0.78 \pm 0.14^{f}$ & $0.80 \pm 0.16^{f}$ & $0.82 \pm 0.14^{\dagger}$ & $0.90 \pm 0.17^{f}$ \\
\hline NFE ${ }^{\star *}$ & $\begin{array}{c}72.30 \pm 1.4 \\
0^{g}\end{array}$ & $72.10 \pm 1.20^{g}$ & $71.91 \pm 1.30^{g}$ & $71.38 \pm 1.18^{g}$ & $71.24 \pm 1.32^{\mathrm{g}}$ & $70.95 \pm 1.39^{g}$ \\
\hline $\begin{array}{l}\text { Energy value } \\
\text { (Kcal) }\end{array}$ & $\begin{array}{c}463.90 \pm 3.2 \\
0^{h}\end{array}$ & $\underset{h}{465.00 \pm 3.28}$ & $\underset{\mathrm{h}}{465.40 \pm 3.40}$ & $468.04 \pm 3.58^{h}$ & $468.37 \pm 3.70^{h}$ & $469.03 \pm 3.88$ \\
\hline
\end{tabular}


Table (3). Acrylamide contents in biscuits with different levels of biscuit scrap

\begin{tabular}{cc}
\hline Biscuit samples & Acrylamide $\boldsymbol{\mu g} / \mathbf{k g}$ \\
\hline Biscuit (control) (250 kg wheat flour) & $294 \pm 10 \mathrm{a}$ \\
Biscuit Scrap & $291 \pm 11 \mathrm{a}$ \\
$+12.5 \mathrm{~kg} \mathrm{Scrap}$ & $281 \pm 8 \mathrm{~b}$ \\
$+25.0 \mathrm{~kg} \mathrm{Scrap}$ & $261 \pm 10 \mathrm{c}$ \\
$+37.5 \mathrm{~kg} \mathrm{Scrap}$ & $224 \pm 9 \mathrm{~d}$ \\
$+50.0 \mathrm{~kg}$ Scrap & $197 \pm 7 \mathrm{e}$
\end{tabular}

Means in column sharing the same superscript letter are not significantly different $(p \leq 0.05)$

\section{Physical properties}

\section{Physical measurements of prepared biscuits}

The effect of adding biscuit scrap powder $(12.5,25.0,37.5$ and $50.0 \mathrm{~kg})$ with wheat flour on the physical properties of biscuit (weight, length, width, thickness, volume and specific volume) were measured and the results are shown in Table (4). Results showed that there were no significant $(p \leq 0.05)$ differences in length and width of biscuits without scrap (control) and biscuits with different levels of scrap.

Thickness was increased from $0.4 \mathrm{~cm}$ in control to $0.48 \mathrm{~cm}$ in biscuits prepared with adding $50 \mathrm{~kg}$ scrap. That mean prepared biscuits with more scrap are crispier than control biscuits. The spread factor is an indicator of biscuit. The changes in thickness were reflected in spread ratio of biscuits so that spread ratio decreased from 8.25 in control biscuits to 6.88 in prepared biscuits with adding $50 \mathrm{~kg}$ scrap. Reduced spread ratios of fortified biscuits were attributed to the fact that biscuit scrap apparently formed aggregates with increased numbers of hydrophilic sites available that competed for the limited free water in biscuit dough (McWatters, 1978 and Sathe et al., 1981). A decrease in spread ratio of biscuits was reported by many workers (Singh et al., 2008 and Laura et al., 2012) who blended wheat flour with other different flours.

The volume and weight of biscuits under investigation were significantly $(p \leq 0.05)$ increased with addition of biscuit scrap powder so that specific volume significantly increased. The increase in biscuit weight was probably due to the ability of scrap flour to retain oil during baking process. These results are in agreement with the results of Rufeng et al., (1995) and Saadoudi et al. (2017) who concluded that jujube flour was able to retain oil during baking process of biscuits. 
J. Adv. Agric. Res. (Fac. Agric. Saba Basha)

Table (4). Physical measurments of biscuits with different levels of biscuit scrap

\begin{tabular}{lccccc}
\hline & \multicolumn{5}{c}{ Biscuit samples } \\
\cline { 2 - 6 } \multicolumn{1}{c}{ Parameters } & Control & $\mathbf{+ 1 2 . 5} \mathbf{~ k g}$ & $\mathbf{+ 2 5 . 0 ~ k g}$ & $\mathbf{+ 3 7 . 5 ~} \mathbf{~ g g}$ & $\mathbf{+ 5 0 . 0 ~ k g}$ \\
& $\mathbf{2 5 0} \mathbf{~ k g}$ & Scrap & Scrap & Scrap & Scrap \\
\hline Length $(\mathbf{c m})$ & $5.00 \pm 0.12 \mathrm{a}$ & $5.00 \pm 0.12 \mathrm{a}$ & $5.00 \pm 0.11 \mathrm{a}$ & $5.00 \pm 0.11 \mathrm{a}$ & $5.00 \pm 0.12 \mathrm{a}$ \\
Width $(\mathbf{c m})$ & $3.30 \pm 0.08 \mathrm{~b}$ & $3.30 \pm 0.09 \mathrm{~b}$ & $3.30 \pm 0.06 \mathrm{~b}$ & $3.30 \pm 0.06 \mathrm{~b}$ & $3.30 \pm 0.08 \mathrm{~b}$ \\
Thickness $(\mathbf{c m})$ & $0.48 \pm 0.02 \mathrm{c}$ & $0.43 \pm 0.01 \mathrm{~d}$ & $0.45 \pm 0.02 \mathrm{~d}$ & $0.45 \pm 0.02 \mathrm{~d}$ & $0.48 \pm 0.02 \mathrm{~cd}$ \\
Spread ratio Width/thickness & $6.88 \pm 0.16 \mathrm{e}$ & $7.67 \pm 0.19 \mathrm{f}$ & $7.33 \pm 0.18 \mathrm{fg}$ & $7.30 \pm 0.18 \mathrm{~g}$ & $6.88 \pm 0.16 \mathrm{e}$ \\
Volume $(\mathbf{c m} 3)$ & $10.90 \pm 0.25 \mathrm{~h}$ & $10.75 \pm 0.24 \mathrm{~h}$ & $10.80 \pm 0.22 \mathrm{~h}$ & $10.82 \pm 0.22 \mathrm{~h}$ & $10.90 \pm 0.25 \mathrm{~h}$ \\
Weight $\mathbf{( g )}$ & $3.73 \pm 0.09 \mathrm{i}$ & $3.53 \pm 0.08 \mathrm{j}$ & $3.60 \pm 0.06 \mathrm{j}$ & $3.66 \pm 0.06 \mathrm{jk}$ & $3.73 \pm 0.09 \mathrm{i}$ \\
Specific volume (cm3/g) & $2.92 \pm 0.05 \mathrm{l}$ & $3.04 \pm 0.06 \mathrm{l}$ & $3.00 \pm 0.05 \mathrm{~lm}$ & $3.00 \pm 0.05 \mathrm{~lm}$ & $2.92 \pm 0.05 \mathrm{l}$ \\
\hline \multicolumn{1}{c}{ Means in each raw sharing the same superscript letter are not significantly different $(\mathrm{p} \leq 0.05)}$.
\end{tabular}

\section{Color parameters of prepared biscuits crusts}

Color is an important attribute because it can arouse individual's appetite. It is one of the parameters used for process control during baking and roasting, because brown pigments appear as browning and caramelization reactions progress (Pereira et al., 2013). The color parameters of pieces biscuit obtained from wheat flour and biscuit blended with scrap were shown in Table (5).

The results showed that crust lightness $\left(L^{*}\right)$ was significantly $(p \leq 0.05)$ decreased when the level of biscuit scrap powder increased in the blends. The $L^{*}$ value in control sample was 71.05 while in prepared biscuits blended with $50.0 \mathrm{~kg}$ biscuit scrap powder was 64.34 so that biscuit crust with high level of biscuit scrap powder had darker crust. That could be due to the Maillard reaction with a consequent increase of melanoidin formation, resulting in a darkening of the product.

The redness values $\left(a^{*}\right)$ of biscuit crust pieces increased when biscuit scrap increased due to nature of biscuit scrap powder. The $\left(a^{*}\right)$ value in control sample was 9.57 while in prepared biscuits blended with $50.0 \mathrm{~kg}$ biscuit scrap powder was 12.56 .

The yellowness value $\left(b^{*}\right)$ for biscuit crust was also significantly increased when biscuit scrap powder increased. The $\left(b^{*}\right)$ value in control sample was 37.01 , while in prepared biscuits added with $50.0 \mathrm{~kg}$ biscuit scrap powder was 38.70 .

The color of the biscuits changed to dark brown as the inclusion level of biscuit scrap increased. This may be due to the ingredient composition, air velocity in the oven, and red pigmentation resulting from the Maillard reaction or nonenzymatic browning which depends on the content of reducing sugars and amino acids or proteins on the surface, baking temperature, and time (Pereira et al., 2013).

The results obtained by Srivastava et al., (2010) stated that the values of $L^{*}$ decreased when biscuits was incorporated with virgin coconut meal while both $a^{*}$ and $b^{*}$ increased. Wang et al. (2015) reported that increasing the amount of quinoa flour in the composite flour increased darkness and 
redness of bread. The increasing of darkness and redness of quinoa based bread might be due to the high content of protein in quinoa flour.

Thejasri et al.(2017) observed the effect of hydrocolloids on $\mathrm{L}^{*}$, $\mathrm{a}^{*}$ and $b^{*}$ values of the prepared biscuits. They reported that wheat biscuits had highest $L^{*}$ values followed by biscuits blended with guar gum, xanthan gum and quinoa, this might be due to the high protein content, sugars and phenolic compounds of formulations with higher proportions of quinoa flour. That could be due to the Maillard reaction with a consequent increase of melanoidin formation, resulting in a darkening of the product (Singh et al., 2007, Secchi et al., 2011 and Zucco et al., 2011). In addition, oxidation of phenolic compounds present in quinoa flour consequent formation of dark pigments may also have interfered (Takata et al., 2007 and Adelakun et al., 2012).

Table (5). Colour parameters of biscuits crusts with different levels of biscuit scrap

\begin{tabular}{|c|c|c|c|}
\hline \multirow{2}{*}{ Biscuit samples } & \multicolumn{3}{|c|}{ Parameters } \\
\hline & $\mathrm{L}^{*}$ & $\mathbf{a}^{*}$ & $\mathbf{b}^{*}$ \\
\hline $\begin{array}{l}\text { Biscuit (control) (250kg } \\
\text { wheat flour) }\end{array}$ & $71.05 \pm 0.35 a$ & $9.57 \pm 0.07 f$ & $37.01 \pm 0.12 k$ \\
\hline $\begin{array}{l}+12.5 \text { kg Scrap } \\
+25.0 \mathrm{~kg} \text { Scrap } \\
+37.5 \mathrm{~kg} \text { Scrap } \\
+50 \mathrm{~kg} \text { Scrap }\end{array}$ & $\begin{array}{l}68.08 \pm 0.32 b \\
67.43 \pm 0.31 c \\
66.50 \pm 0.32 d \\
64.34 \pm 0.30 e\end{array}$ & $\begin{array}{r}10.74 \pm 0.08 \mathrm{~g} \\
11.15 \pm 0.08 \mathrm{~h} \\
11.90 \pm 0.09 \mathrm{i} \\
12.56 \pm 0.10 \mathrm{j}\end{array}$ & $\begin{array}{c}37.53 \pm 0.121 \\
37.85 \pm 0.13 \mathrm{~m} \\
38.23 \pm 0.13 \mathrm{n} \\
38.70 \pm 0.140\end{array}$ \\
\hline
\end{tabular}

\section{Rheological properties of dough samples}

\section{Farinograph properties of dough}

Farinograph is frequently used to evaluate the rheological properties of dough such as water absorption of flour and to determine other characteristics of dough during mixing and establishes the flour behavior during the biscuit making process. Table (6) showed the rheological properties of wheat dough with different blends of biscuit scraps. Data showed that the water absorption significantly $(p \leq 0.05)$ increased with the increase of biscuit scrap powder. The increase in water absorption is probably due to the increase in total protein content of mixed wheat flour with biscuit scrap (Hegazy and Faheid, 2006).

The results showed that the arrival time increased with increasing level of biscuit scrap powder. These results are in agreement with the results of Amir et al., (2015) and Rizk et al. (2016) who found that water absorption gradually increased with the increase of wheat flour added with sorghum or chickpea flour and also they found that departure time and stability decreased as the amount of substituted sorghum and chickpea flour increased where as arrival time increased.

The dough development time refer to the time required for the dough development or time necessary to reach 500 Brabender unit (BU) of dough consistency. Dough development time of wheat flour dough with different 
blends of biscuit scrap powder was significantly $(p \leq 0.05)$ increased with the increase the biscuit scrap powder. Differences in dough development time of control and blends of biscuit scrap powder may be due to differences in the physicochemical properties between the constituents of biscuit scrap powder and those of the wheat flour. Also the difference in the rate of water absorption by wheat and biscuit scrap powder and due to higher amounts of soluble proteins in wheat flour resulted in longer dough development time. These results are in agreement with earlier results of Tomoskozi et al. (2011) who reported that addition of quinoa flour to wheat flour increased the dough development time. They added that the starch constituents of quinoa flour may play the most important role in the longer time of the dough development.

Stability value is an index of the dough strength; high values are indicating stronger dough. Stability time was significantly $(P \geq 0.05)$ decreased with the increase of biscuit scrap powder. The wheat (control) dough was the highest dough stability value $(10 \mathrm{~min})$. Differences in the dough sample containing from 12.5 to $50 \mathrm{~kg}$ biscuit scrap powder exhibited higher stability and resistance to mechanical mixing values. The low dough stability of the wheat flour blended with biscuit scrap flour might be due to high fiber content which destroyed the gluten matrix. These results are in agreement with Abdelghafor et al. (2013), they found that farinograph properties such as stability decreased as the amount of substituted sorghum increased. The decrement in the stability time indicates weakness of dough strength. This weakness of the dough may be due to using scrap flour which reduced the wheat gluten content (dilution effect) in the blends which make the dough more weak strength (Singh et al., 1991).

The results of Enriquez et al. (2003) showed that blends containing 5 or $10 \%$ of quinoa flour showed good bread making properties. However, biscuit scrap powder blends up $50 \mathrm{~kg}$ had good stability time against the control. In this case we can emphasize that, addition of biscuit scrap powder with wheat flour up to $50 \mathrm{~kg}$ had a positive effect on the rheological characteristics of dough. Value for subsequent stability of $6.5 \mathrm{~min}$ suggested that the dough might well perform under mechanical influences during the kneading and processing (Stikic et al., 2012).

The degree of softening of wheat flour with biscuit scrap powder blends was significantly increased as it was 40 and $60 \mathrm{BU}$ in control and and prepared biscuit added with $50 \mathrm{~kg}$ biscuit scrap powder respectively. However, there were no significant differences between control dough and dough containing biscuit scrap powder $12.5 \mathrm{~kg}$. The weakening or degree of softening in biscuit prepared with 37.5 and $50.0 \mathrm{~kg}$ biscuit scrap powder was high about other blends, and probably due to the network proteins which diluted and caused an increase in degree of softening value. These results are in agreement with earlier results of Abdelrahman (2014) who found that addition of lupine flour to wheat flour at different amounts cause weakening in wheat dough. He added that; variation in hydration behavior of two proteins may be reason for differences in dough characteristics. From the obtained data in the present study, the addition of biscuit scrap powder with wheat flour had a slight effect on rheological properties. 


\section{Extensograph properties of dough}

Extensograph provides information about the viscoelastic behavior of dough (Rosell et al., 2001). This equipment measures dough extensibility and resistance to extension. A combination of good resistance and good extensibility results is needed in dough properties (Walker and Hazelton, 1996). Data in Table (7) showed that rheological properties of wheat flour dough with different ratio of biscuit scrap powder by extensograph. The resistance of extension (elasticity) depends on the amount of glutenine in dough. The elasticity was significantly $(p \leq 0.05)$ decreased with the increase of biscuit scrap powder amount. The wheat dough (control) showed higher elasticity value than wheat flour with biscuit scrap flour. Elasticity decreased in biscuit scrap powder with wheat flour blends dough due to wheat flour characteristics as gluten free.

Table (6). Farinograph parameters of dough with added biscuit scrap flour

\begin{tabular}{|c|c|c|c|c|c|}
\hline \multirow[b]{2}{*}{ Biscuit formula } & \multicolumn{5}{|c|}{ Biscuit samples } \\
\hline & $\begin{array}{c}\text { Water } \\
\text { absorption\% }\end{array}$ & $\begin{array}{c}\text { Arrival } \\
\text { time (min) }\end{array}$ & $\begin{array}{c}\text { Development } \\
\text { time (min) }\end{array}$ & $\begin{array}{c}\text { Stability } \\
\text { time (min) }\end{array}$ & $\begin{array}{c}\text { Degree of } \\
\text { softenning BU }\end{array}$ \\
\hline $\begin{array}{l}\text { Biscuit (control, } \\
250 \text { kg wheat } \\
\text { flour) }\end{array}$ & $51.8 \pm 0.10 a$ & $0.5 \pm 0.10 f$ & $1.0 \pm 0.12 \mathrm{k}$ & $10.0 \pm 0.11 p$ & $40 \pm 0.12 u$ \\
\hline + 12.5 kg Scrap & $53.7 \pm 0.08 b$ & $1.5 \pm 0.08 g$ & $2.0 \pm 0.09 \mid$ & $8.5 \pm 0.06 q$ & $40 \pm 0.08 v$ \\
\hline+25.0 kg Scrap & $55.4 \pm 0.02 c$ & $2.5 \pm 0.02 h$ & $2.5 \pm 0.01 \mathrm{~m}$ & $7.5 \pm 0.02 r$ & $50 \pm 0.02 w$ \\
\hline + 37.5 kg Scrap & $57.5 \pm 0.26 d$ & $2.5 \pm 0.24 \mathrm{i}$ & $3.0 \pm 0.19 n$ & $7.0 \pm 0.18 \mathrm{~s}$ & $55 \pm 0.16 x$ \\
\hline + 50 kg Scrap & $59.8 \pm 0.22 e$ & $3.0 \pm 0.25 j$ & $4.0 \pm 0.240$ & $6.5 \pm 0.22 t$ & $60 \pm 0.25 y$ \\
\hline
\end{tabular}

Table (7). Extensograph parameters of dough with added biscuit scrap flour

\begin{tabular}{|c|c|c|c|c|}
\hline \multirow[b]{2}{*}{ Biscuit formula } & \multicolumn{4}{|c|}{ Biscuit samples } \\
\hline & $\begin{array}{l}\text { Elasticity } \\
\text { (B.U) }\end{array}$ & $\begin{array}{l}\text { Extensibility } \\
(\mathrm{mm})\end{array}$ & $\begin{array}{l}\text { Ratio } \\
\text { Number }\end{array}$ & $\begin{array}{l}\text { Energy } \\
(\mathrm{Cm} 2)\end{array}$ \\
\hline $\begin{array}{l}\text { Biscuit (control, } 250 \mathrm{~kg} \\
\text { wheat flour) }\end{array}$ & $680 \pm 35 a$ & $85 \pm 10 f$ & $8 \pm 1 k$ & $85 \pm 11 p$ \\
\hline+12.5 kg Scrap & $610 \pm 30 b$ & $105 \pm 11 \mathrm{~g}$ & $5.8 \pm 11$ & $75 \pm 6 q$ \\
\hline+25.0 kg Scrap & $600 \pm 24 c$ & $95 \pm 12 h$ & $5.9 \pm 1 \mathrm{~m}$ & $45 \pm 5 r$ \\
\hline + 37.5 kg Scrap & $490 \pm 22 d$ & $85 \pm 10 i$ & $5.76 \pm 1 n$ & $35 \pm 4 s$ \\
\hline+50 kg Scrap & $420 \pm 18 e$ & $65 \pm 11 j$ & $5.50 \pm 20$ & $25 \pm 3 t$ \\
\hline
\end{tabular}

The extensibility of the dough is the ability of the dough to extend or stretch, it depends on the gliadin protein in the dough. Dough extensibility was significantly decreased with the high ratio from biscuit scrap powder. No significant $(p \leq 0.05)$ differences in the control (wheat dough) and $15 \%$ biscuit scrap powder dough were $85 \mathrm{~mm}$ respectively. The wheat flour with $20 \%$ biscuit scrap powder was the lowest value than all blends. The wheat flour with $5 \%$ biscuit scrap powder was the highest value than other blends from 
biscuit scrap powder. While the blends containing 37.5 and $50 \mathrm{~kg}$ biscuit scrap powder were the lowest extensibility value, 65 and $85 \mathrm{~mm}$ respectively. The variances in rheological properties among wheat flour and biscuit scrap powder might commonly be attributed to the difference in chemical composition and structure of the constituents including protein and starch, and their relations (Wang et al., 2015).

This result is in agreement with earlier results of Enriquez et al., (2003) who reported that addition of quinoa flour at ratio 5, 10 and $15 \%$ to wheat flour decreased the extensibility significantly, also they found decrease the extensibility affected by the absence of gluten-like protein in quinoa flour.

Generally, in this study biscuit scrap powder flour had slight effect on dough properties such as elasticity and extensibility, good value for these parameters able to using biscuit scrap powder in biscuit making at high amount to $37.5 \mathrm{~kg}$ without any effect on rheological properties of dough. Our challenge in the present study was the ability to use biscuit scrap powder in biscuit making at high amount up to $15 \%$ without dramatic effect on rheological properties of dough. Ratio number is the ratio of elasticity /extensibility. Ratio number was significantly decreased by adding biscuit scrap powder to wheat flour. The control (wheat flour) had the highest ratio than other blends. No significant $(p \geq 0.05)$ differences among $5 \%$ and $10 \%$ biscuit scrap powder. However, the blend containing $50 \mathrm{~kg}$ biscuit scrap powder was the lowest ratio value (5.50).

The area under beak (energy $\mathrm{cm}^{2}$ ) required for dough mixing, was significantly decreased due to adding biscuit scrap powder at high levels (over $12.5 \mathrm{~kg}$ ). No data was found on reological studies of biscuits blended with biscuit scrap flour.

\section{CONCLUSION}

The chemical composition of prepared biscuits blended with different levels of scrap were not significantly $(p \geq 0.05)$ different while fat content and energy value slightly increased with increasing the level of biscuit scrap. The acrylamide levels in produced biscuits decreased by increasing biscuit scraps due to increasing baking time and temperature up to $260{ }^{\circ} \mathrm{C}$ particularly in the outer crust. Physical measurements showed no significant $(p \geq 0.05)$ differences in length and width of prepared biscuits with or without scrap. On the other hand, thickness, volume and weight were significantly $(p \geq 0.05)$ increased and spread factor was significantly $(p \geq 0.05)$ decreased.

The color parameters of biscuit showed that lightness $\left(\mathrm{L}^{*}\right)$ was significantly decreased while the redness values $\left(a^{*}\right)$ and yellowness value $\left(b^{*}\right)$ of biscuit crust significantly increased with adding biscuit scrap flour to wheat flour. Rheological properties as farinograph and extensograph of dough slightly affected. Generally, it could be concluded that, adding of biscuit scrap powder up to $50 \mathrm{~kg}$ to $250 \mathrm{~kg}$ wheat flour has slightly effect on chemical, physical and rheological properties and the most benefits its reduced 
acrylamide in produced biscuits. This work paves the way for manufacturers to use biscuit scrap produced from previous batches safely in producing biscuits.

\section{REFERENCES}

Adelakun,O.E.,Kudanga,T.,Parker,A.(2012).Laccase-catalyzed dimerization of ferulic acid amplifies antioxidant activity. J. of Molecular Catalysis Enzyme, 7, 29-35.

Abdelghafor, R. F., Mustafa; A. I., A. Ibrahim, M. H., Chen, Y. R. and Krishnan, P. G. (2013). Effect of sorghum flour addition on chemical and rheological properties of hard white winter wheat. Advance J. Food Sci. and Technol., 5, 1407-1412.

Abdelrahman R. A. (2014). Influence of chemical properties of wheat-lupine flour blends on cake quality. American J. Food Sci. and Technol., 2, 6775.

AACC (2000). Approved methods of American Association of Cereal Chemists, 10th ed. The Association. St, Paul. MN. USA.

Ahrné, L., Andersson, C. G., Floberg, P., Rosén, J.and Lingnert, H. (2007). Effect of crust temperature and water content on acrylamide formation during baking of white bread: Steam and falling temperature baking. LWT, 40, 1708-1715.

Amir, B., Mueen-ud-din, G., Abrar, M., Mahmood, S., Nadeem, M.and Mehmood, A. (2015). Chemical composition, rheological properties and cookies making ability of composite flours from maize, sorghum and wheat. J. Agroaliment Proc. Technol., 21, 28-35.

Andresen, M. S., Dissing, B. S., and Loje, H. (2013). Quality assessment of butter cookies applying multispectral imaging. Food Sci. and Nutri., 1, 315-323.

AOAC (2006). Association of Official Analytical Chemists. Official Method of Analysis, Edn. 17, Washington DC.

Borda, D. and Alexe, P. (2011). Acrylamide levels in food. Romanian J. Food Sci., 1, 3-15.

Caleja, C., Barros, L., Antonio, A. L., Oliveira, M. B. and Ferreira, I. C. (2017). A comparative study between natural and synthetic antioxidants: Evaluation of their performance after incorporation into biscuits. Food Chemistry, 216, 342-346.

Calligaris, S., Pieve, S.D., Kravina, G., Manzocco, L., Nicoli, C.M. (2008). Shelf life prediction of bread sticks using oxidation indices: A validation study, J. Food Sci., 73, 2, E51-E56

Caponio, F., Summo, C., Delcuratolo, D. and Pasqualone, A. (2006). Quality of the lipid fraction of Italian biscuits. J. Sci. Food and Agric., 86, 356-361.

Chauhan, A., Saxena, D. C. and Singh, S. (2015). Total dietary fiber and antioxidant activity of gluten free cookies made from raw and germinated amaranth (Amaranthus spp.) flour. LWT - Food Sci. and Technol., 63, 939-945.

Davidson, I. (2018). Biscuit, Cookie and Cracker Production. Academic Press, London. 
Duncan, M. (2009). Biscuits, Cracker and Cookie recipe for the food industry, Third edition, Woodhead Publishing in Food Science and Technology.

Enriquez, N., Raimundi, A. and Peltze, M. (2003). Characterization of wheat and quinoa flour blends in relation to their breadmaking quality. Anal. Assoc. Quimica Argentina, 91, 47-54.

Eriksson, S. (2005). Acrylamide in food products: identification, formation and analytical methodology. Ph. D. Thesis. Stockholm University, Sweden.

Gokmen, V., Palazoglu, T. K. and Senyuva, H. Z. (2006). Relation between the acrylamide formation and time-temperature history of surface and core regions of French fries. J. Food Engineering, 77, 972-976.

Graf, M., Amrein, T.M., Graf, S., Szalay, R., Escher, F. and Amadò, R. (2006). Reducing the acrylamide content of a semi-finished biscuit on industrial scale. LWT Food Sci. Technol., 39, 724-728.

Greenfield, H., and Southgate, D. (1992). Determination of Food Carbohydrates, London, Applied Science Publishers.

Gündüz, , C.P., Bilgin, A.K. and Cengiz, M. F. (2017). Acrylamide Contents of Some Commercial Crackers, Biscuits and Baby Biscuits. Akademik Gıda, 15, 1-7.

Gupta, V. (2001). Nutritional and sensory evaluation of value added bakery products. M.Sc. thesis, CCSHAU, Hisar.

Hegazy, N.A. and Faheid, S.M.A. (2006). Rheological and Sensory characteristics of dough and cookies based on wheat, soybean, chickpea and lupine flour. Molecular Nutrition and Food Res., 34, 835 841.

JECFA (2006). Evaluation of certain food contaminants. Sixty-fourth report of Joint FAO/WHO Expert Committee on Food Additives, Geneva.

Jung, M.Y., Choi, D.S. and Ju, J.W. (2003). A novel technique for limitation of acrylamide formation in fried and baked corn chips and in French fries. J. Food Sci. 68, 1287-1290.

Keramat, J., Lebail, A., Prost, C. and Soltanizadeh, N. (2011). Acrylamide in Foods: Chemistry and Analysis (A Review). Food Bioprocess Technol.,4, 340- 363.

Khater, E. G., and Bahnasawy, A. H. (2014). Heat and mass balance for baking process. J. Bioprocessing and Biotechniques, 4, 1-6.

Krishnakumar, T. and Visvanathan, N. (2014). Acrylamide in Food Products: A Review. Food Process Technol., 5, 344-348.

Laura, O., Eric, O. and Emelem, U. (2012). Physicochemical and sensory properties of cookies made from blends of germinated pigeon pea, fermented sorghum and cocoyam flours. Food Sci. and Nutri., 26, 622628.

Levine R.A. and Smith R.E. (2005). Sources of variability of acrylamide levels in a cracker model. J. Agric. Food Chem., 53, 4410-4416.

Liu, J., Zhao, G., Yaun, Y., Chen, F. and Hu, X. (2008). Quantitative analysis of acrylamide in tea by liquid chromatography coupled with electrospray tandem mass spectrometry. Food Chemistry, 108, 760767.

Mamat, H., and Hill, S. E. (2014). Effect of fat types on the structural and textural properties of dough and semi-sweet biscuit. Journal of Food Sci. and Technol., 51, 1998-2005. 
McWatters, K. M. (1978). Cookie baking properties of defatted peanut, soybean and field pea flours in baking powder biscuits. Cereal Chemistry, 55, 853-863.

Okpalan, L. C. and Egwu, P. N. (2015). Utilisation of broken rice and cocoyam flour blends in the production of biscuits. Nigerian Food Journal, 33, 8-11.

Omran, A.A., Ibrahim, O.S. and Mohamed, E.A. (2016). Quality characteristics of biscuit prepared from wheat and flaxseed flour. Advances in Food Sci., 38, 129-138.

Pereira, D., Correia, P. M. and Guine, R. P. (2013). Analysis of the physicalchemical and sensorial properties of cookies. Acta Chimica Slovaca, 6, 269-280.

Razia, S., Bertrand, M., Klaus, V. and Meinolf, G. L. (2016). Investigation of acrylamide levels in branded biscuits, cakes and potato chips commonly consumed in Pakistan. International Food Res. J., 23, 2187-2192.

Rizk, I.R., Elsheshetawy, H.E., Bedeir, S. H., Gadallah, M.G. and AbouElazm, A.M. (2016). Quality Characteristics of Sponge Cake and Biscuit Prepared Using Composite Flour. J. Cereal Sci., 48, 243-257.

Robertson, G. L. (2010). Food Packaging: Principles and Practice, CRC Press, Taylor \&Fransis Group, Boca Raton, London, New York, Third Edition, pp.560-564.

Rosell, C. M., Rojas, J. A., \& De Barber, C. B. (2001). Influence of hydrocolloids on dough rheology and bread quality. Food hydrocolloids, 15(1), 75-81.

Rufeng, N., Enqi, L., Chuangji, C. and Jiangping, Z. (1995). A study of the production of healthy biscuit made with tartary buckwheat grown in North China. Current advances in buckwheat research, 861-865.

Saadoudi, M., Hambaba, L.,Abdeddaim1 and M., Zidani, S. (2017). Nutritional composition, physical properties and sensory evaluation of biscuit produced from jujubes. Annals. Food Sci. and Technol., 18, 395-401.

Sathe, S.K., Tamhane, D.V. and Salunkhe, D.K (1981). Studies in salty cracker (Khara Biscuits), protein enriched and storage stability, Cereal Food World, 26, 407-409.

Secchi, N., Stara, G. and Anedda, R. ( 2011). Effectiveness of sweet ovine whey powder in increasing the shelf life of Amaretti cookies. LWT Food Science and Technology, 44, 1073-1078.

Semla M., Goci, Z., Martiniak, M. And Formicki, N. (2017). Acrylamide: A common food toxin related to physiological functions and health. Physiol. Res. 66, 205-217.

Sharma, S., Saxena, D. C. and Riar, C. S. (2016). Nutritional, sensory and in-vitro antioxidant characteristics of gluten free cookies prepared from flour blends of minor millets. Journal of Cereal Sci., 72, 153-161.

Singh, N.K., Harinder, K.S. and Sekhon, B.S. (1991). Study on the improvement of functional and baking properties of wheat-chickpea flour blends. Ph.D.Thesis, Department of Sci. and Technol., Punjab Agriculture University, Ludhiana, India. 
Singh, M. and Mohamed, A. ( 2007). Influence of gluten-soy protein blends on the quality of reduced carbohydrates cookies. Food Sci. and Technol., 40, 353-360.

Singh, S., Ria, C. S. and Saxena, D. C. (2008). Effect of incorporating sweet potato to wheat flour on the quality characteristics of cookies. Afr. J. Food sci., 2, 65-67.

Srivastava, Y., Tamhane D.V. and Meinolf, G. (2010). Effect of virgin coconut meal (VCM) on the textural, thermal and physico chemical properties of biscuits. Food and Nutrition Sci., 1, 38-44.

Steel, R.G.D. and Torrie, J.H. (1980). Principles and Procedures of Statistics. A Biometrical approach. 2nd ed., McGraw Hill Book Co. Inc. New York.

Stikic, R., Glamoclija, D. and Demin, M. (2012). Agronomical and nutritional evaluation of quinoa seeds as an ingredient in bread formulations. Journal of Cereal Science, 55, 132-138.

Sudha, M. L., Vetrimani, R. and Leelavathi, K. (2007). Influence of fiber from different cereals on the rheological characteristics of wheat flour dough and on biscuit quality. Food Chemistry, 100, 1365-1370.

Takata, K., Yanaka, M., Fujita, Y., Ishikawa, N. (2007). Evaluation of the grain and flour quality in near-isogenic wheat lines with waxy and doublenullWx proteins. Breeding Sci., 57, 79-83.

Thejasri, V., Hymavathi, T. V., Roberts, T. P., Anusha, B. and Devi, S. S. (2017). Sensory, physico-chemical and nutritional properties of gluten free biscuits formulated with guinoa (Chenopodium quinoa Willd.), foxtail millet (Setaria italica) and Hydrocolloids. Int. J. Curr. Microbiol. App. Sci., 6, 1710-1721.

Tömösközi, S., Gyenge, L., Pelcéder, Á., Abonyi, T., Schönlechner, R. and Lásztity, R. (2011). Effects of flour and protein preparations from amaranth and quinoa seeds on the rheological properties of wheat-flour dough and bread crumb, Czech J. Food. Sci., 29, 109-116

Wade, W. and Stafford, S. (1968). The chemical analysis of foods. 7th Edition. Churchill live store, p. 205-206.

Walker, C. E. and Hazelton, J.L. (1996). Dough rheological tests. Cer. Foods World, 41, 23-28.

Wang, X., He, S., Zhang, P., Xie, Y. and Zhang, M. (2015). The pheological properties of polysaccharides from rapeseeds. Current Topic in Nutritional Res., 13, 197-204.

Whitely, P. R. (1971). Biscuit manufacture. In: P.R. Whitely (Ed), Fundamentals of inline production. Elsevier Publishing Company, Amsterdam, 359 - 412 p.

Ye, H., Miao, Y., Zhao, C. and Yuan, Y. (2011). Acrylamide and methylglyoxal formation in potato chips by microwaving and frying heating. International Journal of Food Sci. and Technol., 46, 19211926.

Youssef, M. K., Nassar, A.G., EL-Fishawy, F. A. and Mostafa, M.A. (2016). Assessment of proximate chemical composition and nutritional status of wheat biscuits fortified with oat powder. Assiut J. Agric. Sci., 47, 8394.

Yuan, Y. Shu, C. Zhou, B., Qi, X. and Xiang, J. (2011). Impact of selected additives on acrylamide formation in asparagine/sugar Maillard model systems. Food Res. International, 44, 449-455. 
Zhang, Y., Zhang, G. and Zhang, Y. (2005). Occurrence and analytical methods of acrylamide in heat-treated foods: Review and Recent Developments. J. Chromatography A, 1075, 1-21.

Zucco, F., Borsuk, Y. and Arntfield, SD. (2011). Physical and nutritional evaluation of wheat cookies supplemented with pulse flours of different particle sizes. LWT Food Sci. and Technol., 44, 2070-2076.

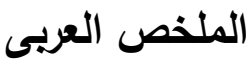

\section{خصائص الجودة للبسكويت المجهز من دقيق القمح ومسحوق فاقد البسكويت}

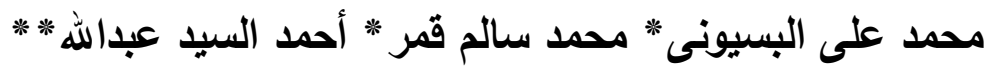

الشركة المصرية للأغذية- بسكو مصر * وكلية الزراعة سابا بانا - جامعة الإسكندرية *

أجريت هذه الدراسة لمعرفة تأثثر إضافة مستويات مختلفة من مسحوق فاقد البسكويت (غير المطابق

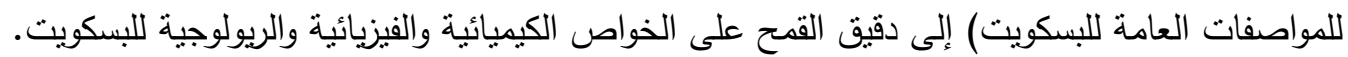

لم ينأثر التركيب الكيميائي معنوياً للبسكويت المجهز من دقيق القمح المضاف إلية معدلات مختلفة من مسحوق فاقد البسكويت مقارنة بالبسكويت الدجز من دقيق القمح بينما كان هناك زيادة في الدهون والسعرات الحرارية

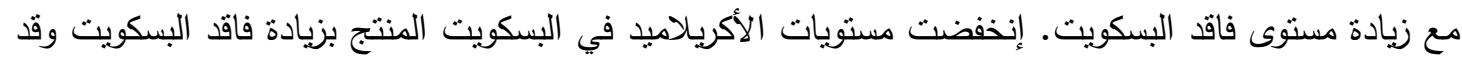
برجع ذللك إلى زيادة الوقت وإرتقاع درجة حرارة الخبيز في القشرة الخارجية للبسكويت. أظهرت القياسات الفيزيائية عدم وجود فروق معنوية في طول وعرض البسكويت المحضر مع أو بدون فاقد البسكويت بينما زاد السمك والحجم والوزن وانخفض عامل الانتشار بشكل ملحوظ. أوضحت قياسات اللون للبسكويت إنخفاض قيم اللون الفاتح بينما زادت قيم اللون الأحمر والأصفر لقشرة البسكويت مع إضافة الفئة الفاقد إلى دقيق القمح.

كما أوضحت الدراسات الريولوجية نأثيرات طفيفة غير معنوية في البسكويت المضاف إلية معدلات مختلفة من

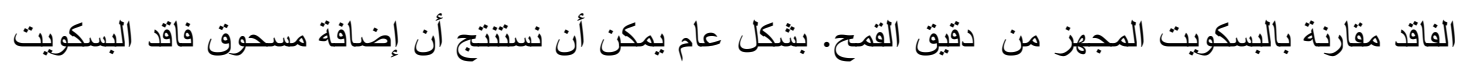

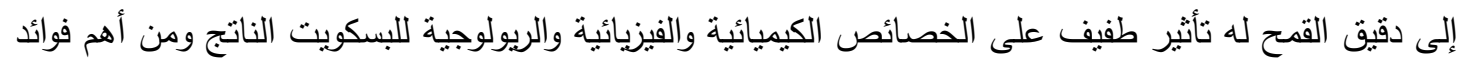

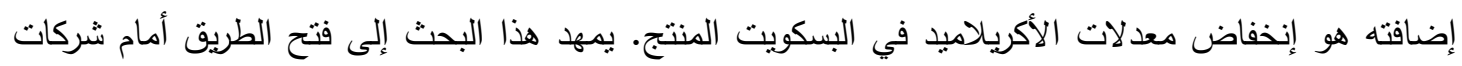
الأغذية المصنعة للبسكويت للإستخدام الأمن لفاقد البسكويت بالتركيزات التي تم دراستها في إنتاج البسكويت. 